\title{
Aptidões biofísicas e intensificação agroecológica da pecuária leiteira em assentamentos da Amazônia brasileira
}

\author{
Land suitability and agroecological dairy production of smallholders in \\ agrarian reform settlements, in Brazilian Amazon.
}

\author{
Laura Angélica Ferreira Darnet'他, René Jean Marie Poccard-Chapuis "(i) , Lívio Sérgio \\ Dias Claudino III) , Soraya Abreu Carvalho IV(1) \\ 'Universidade Federal Do Pará, Belém, PA, Brasil \\ "Centro de cooperação internacional em pesquisa agronômica para o desenvolvimento, Brasília, DF, Brasil \\ III Universidade Federal Do Pará, Belém, PA, Brasil \\ Iv Universidade Federal Do Pará, Belém, PA, Brasil
}

\section{RESUMO}

Melhorar as atividades agrícolas e a proteção dos recursos naturais, especialmente na Amazônia e nas áreas de assentamentos da reforma agrária, concebendo sistemas sustentáveis a partir de paisagens e coeficientes é uma alternativa promissora e está sendo implantada em Paragominas, no Pará, a partir do Plano Municipal de Inteligência Territorial. Este artigo analisa em que medida o microzoneamento proposto no Plano é coerente com as possibilidades de intensificação agroecológica da produção forrageira em propriedades leiteira familiares, e se os ajustes de uso da terra correspondem às aptidões biofísicas das propriedades. $O$ estudo de caso foi realizado na Comunidade de Nova Jerusalém, do Assentamento Luiz Inácio e se apoiou nos dados georreferenciados do Plano Municipal, além de entrevistas com as famílias e acompanhamento de experimentos de produção forrageira em campo. Utiliza o software Arcgis (c) para compilar e cruzar informações espaciais em formato shape. Os resultados apontam que na comunidade estudada $56 \%$ das famílias têm condições favoráveis para seguir o Plano, tendo em vista as aptidões nas suas propriedades, mas há famílias em que a propriedade se encontra em condições biofísicas restritas para produção forrageira, requerendo atenção especial.

Palavras-chave: Agricultura Familiar; Agroecologia; Aptidões Biofísicas; Pecuária Leiteira; Produção Forrageira

\section{ABSTRACT}

Combining agricultural activities and natural resources protection is a current emergency around the world, especially in the Amazon and smallholders. Building eco-efficient landscape is a promising alternative for sustainable local development, and the Paragominas municipality is including this objective in its Jurisdictional Intelligent Plan for Local Development. The microzoning tool proposed in the Plan is mapping specific areas in 
all rural properties, with higher suitability for agricultural intensification or forest restoration. Land and biophysical conditions are defining the suitability. The objective of this study is to analyze how this tool can work and promote sustainability, specifically for smallholders, dairy producers in an agrarian reform settlement. This case study was carried out in the Community of New Jerusalem, in the Luiz Inácio Settlement, and was based on georeferenced data, in addition to interviews with the families and monitoring of forage production field experiments. We used the Arcgis (c) software to compile and cross-check spatial information in shape format, from the Municipal Plan. The results indicate that in the community studied $56 \%$ of the families have favorable conditions to follow the Plan and improve agroecological forage production, given the biophysical situation of their properties. But the other families have low biophysical conditions, restricting the possibilities to intensify forage production, and special attention should be given to this group

Keywords: Agroecology; Dairy Production; Forage Production; Land Suitability; Smallholders

\section{INTRODUÇÃO}

A pecuária bovina na Amazônia tem sido apontada como uma das atividades que mais causam prejuízos ambientais, especialmente por demandarem o desmatamento para a implantação de pastagens. Por sua boa adaptação às condições pedoclimáticas, além de relativa disponibilidade de terras em alguns locais, a atratividade foi grande, levando à expansão dos rebanhos bovinos desde os anos 1960. Aliam-se a esses motivos os fatores econômicos, ambientais, sociais e culturais (VEIGA et al., 2004; VAZ et al., 2012; CARVALHO et al., 2015), incluindo as imagens e os discursos que foram gradualmente sendo produzidos sobre a pecuária bovina para a região (CLAUDINO, 2016). Por outro lado, houve também um intenso trabalho, de agentes políticos e de diversas instituições, para frear os avanços, como os limites ao desmatamento impostos no final dos anos 2000 (POCCARD-CHAPUIS et al. 2015; CIALDELLA et al, 2015).

Entre os estados componentes da Amazônia brasileira, o Pará ocupou lugar de destaque, tendo ainda a expansão continuado mesmo em período mais recente, apesar das restrições. Dados do Instituto Nacional de Pesquisas Espaciais (INPE, 2019), se comparado a todos os estados que compõem a Amazônia Legal Brasileira, colocam o Pará na liderança do desmatamento entre os anos 2013 a 2018. Regionalmente, o sul e o sudeste do Pará lideraram as estatísticas, enquanto em outras regiões do estado o desmatamento é mais controlado. É o caso de Paragominas, município onde se desenvolveu este estudo. Ali a pecuária surgiu como primeiro processo de ocupação, associando-se durante décadas à extração madeireira, integrando-se, a partir de 2000, 
com a produção mecanizada de grãos em fazendas. Foi quando se iniciou o movimento de intensificação da pecuária, e surgiram práticas de intensificação que podem se enquadrar com o conceito de produção agroecológica (POCCARD-CHAPUIS et al., 2015).

No contexto da agricultura familiar, a pecuária é uma das atividades mais relevante para a composição da renda e uso dos espaços, especialmente no Sudeste Paraense, porém em pastagens geralmente degradadas. Entre a renda que ela proporciona, e os impactos ambientais que ela gera, a pecuária é uma atividade em transformação, quer seja para sistemas intensivos convencionais, intensivos ecológicos (revolução duplamente verde) ou agroecológicos. A gestão pública não foge desse dilema constante, buscando equilíbrios entre a questão ambiental e a manutenção socioeconômica das famílias. Dentre as diversas iniciativas políticas na região, se destaca o Plano de Inteligência e Desenvolvimento Territorial (PIDT) de Paragominas, Decreto $n^{\circ}$ 316, de 24 de maio de 2019, publicado no Diário Oficial Municipal. O Plano prevê a realização de um microzoneamento do uso da terra, para ajustar os diferentes usos do solo em função das aptidões, ou características pedomorfológicas.

Em seus termos, o Plano visa construir uma paisagem ecoeficiente em escala municipal, restaurando florestas em áreas com fortes potenciais para produção de serviços ecossistêmicos por florestas, e valorizar economicamente as áreas mais aptas para a agropecuária. Estudos anteriores realizados no município mostram que na medida em que os agricultores melhoram suas práticas produtivas e intensificam o uso da terra, suas formas de olhar para as condições biofísicas na propriedade, como topografia, drenagem hidrográfica, textura e fertilidade do solo, e até distâncias euclidianas, também mudam. As práticas melhoradas passam a ser realizadas apenas nas melhores condições biofísicas, ao contrário das práticas extensivas, ma is independentes das aptidões do solo (PLASSIN et al., 2017; ONIS et al., 2019; PINILLOS et al., 2020). É essa mudança espontânea de olhares que o Plano quer orientar e incentivar.

Destaca-se que esses estudos não foram realizados contemplando a realidade específica dos assentamentos da reforma agrária, e sim o município como um todo. Diante da importância social da Agricultura Familiar no município, e mais 
especificamente da importância econômica da pecuária nesse grupo social, é necessário avaliar o impacto que o microzoneamento pode alcançar nesse grupo específico. Essa avaliação deve levar em conta os usos da terra ocorrendo na comunidade, no caso, a pastagem, e as opções possíveis para melhorar tais usos por meio da intensificação agroecológica.

O objetivo deste artigo é o de analisar quais áreas o microzoneamento do PIDT indica para a intensificação forrageira, e quais perspectivas de crescimento da produção leiteira são possíveis para as propriedades familiares da comunidade através do microzoneamento.

O artigo está dividido em quatro partes. A primeira é a introdução, seguida de apresentação dos aspectos gerais do lócus de pesquisa. Na segunda parte detalha-se a metodologia, apresentando os conceitos e as regras de cartografia das aptidões biofísicas no PIDT de Paragominas, explicando as análises de dados espaciais realizadas, assim como as entrevistas e os experimentos em campo. Na terceira parte, os resultados são expostos em três partes: i. análise geográfica da comunidade e da sua cartografia no microzoneamento; ii. tipologia das propriedades em função das características de aptidões biofísicas; iii. limites e potencialidades para a intensificação para cada tipo. Por último, as considerações finais.

\subsection{Meio biofísico, produção agropecuária e caminhos para a intensificação ecológica}

De acordo com os protocolos de produção desenvolvidos no campo das ciências agrárias, conhecer as aptidões do solo antes de explorá-lo é o primeiro passo a ser feito. Várias metodologias de classificação das aptidões foram elaboradas e muitos mapas de solo em diferentes regiões do Brasil foram produzidos (LEPSCH et al., 1991; RAMALHO FILHO \& BEEK, 1995; RAMALHO FILHO \& PEREIRA, 1999; PEREIRA \& NETO, 2004; MACEDO et al., 2019; FRANÇA et al., 2019). Entretanto, conciliar estudo prévio de determinada área e disponibilizá-la para uma reforma agrária pensada e planejada é outra situação. A reforma agrária no Brasil se caracteriza por um processo de ocupação 
do espaço e depois legitimação do mesmo como área de reforma agrária (HEREDIA et al., 2002). Nestes termos, as aptidões dos solos que envolvem as áreas não são critérios para a escolha das mesmas.

Como consequência, diferentes trabalhos vêm apontando conflitos entre uso e aptidão do solo, quer seja em área urbana, quer seja em rural, quer seja em bacias hidrográficas (SILVA et al., 2002; PEDRON et al., 2006; NIEMANN, 2012; VILLELA et al., 2015). Esta é a realidade da maioria dos assentamentos da reforma agrária. Muitos foram efetivados pelo processo de desapropriação, seguido de compra e venda de propriedades de um único dono (INCRA, 2020), sendo estas no Brasil classificadas como latifúndios, caracterizadas pelas extensas áreas com monocultivos. No estado do Pará, a criação dos assentamentos rurais se deu predominantemente em áreas com pastagens degradadas. Independentemente da situação, como bem descreve Silva et al. (2010), a realidade das famílias é a de enfrentarem dificuldades no desenvolvimento e manutenção de suas atividades, situação essa que poderia ter sido evitada caso houvesse o planejamento face a implantação de áreas de assentamento.

Em todas essas situações, trata-se no momento de discutir sobre as soluções, os cenários de mudanças e as suas possibilidades. As demandas ecológicas de uso mais racional dos recursos naturais é a pauta principal destas soluções e, em se tratando de Amazônia, este apelo é ainda maior.

Identificar os conflitos de uso da terra entre as aptidões e o uso atual, relacionando com as possibilidades de reformulação de seu uso, parece ser um caminho promissor para recompor sistemas produtivos numa direção mais ecoeficiente. Este é o caso específico da pecuária bovina na Amazônia, atividade pioneira, promissora economicamente, mas altamente consumidora dos recursos naturais. Para PoccardChapuis et al. (2015), o desenvolvimento da pecuária bovina foi baseado na substituição da floresta primária por pastagens, seguida de sua exploração sem uma gestão que possibilitasse sua perenidade e a reposição dos nutrientes ao solo. Acrescenta-se a isso, a baixa carga animal utilizada nas pastagens, o que caracteriza um sistema produtivo extensivo, o qual utiliza mais área do que o necessário para produzir. Esta situação reflete o ciclo de implantação, uso e manejo de pastagens na Amazônia, principalmente 
em estabelecimentos agrícolas familiares. Por exemplo, em estudo realizado na região de São Felix do Xingu, Claudino et al. (2013) identificaram que as diferentes categorias socioeconômicas, dos mais capitalizados aos menos capitalizados, apresentam as mesmas dificuldades com o uso e manutenção das pastagens, havendo diferença nas possibilidades de realizar as reformas, pois quem tem mais capital pode manter os pastos em melhores condições se investir, mas há uma tendência de tratar a pecuária extensiva como a alternativa econômica mais viável.

Neste cenário, o que está em jogo é a capacidade de renovação do potencial das áreas exploradas de forma extensiva. No caso Amazônico, é sabido que os solos, em sua maioria, são ácidos e de baixa fertilidade, visando a um manejo de sua fertilidade que se relacione às práticas em equilíbrio com o meio ambiente, ou uso de fertilizantes, sejam eles naturais ou químicos. Desta forma, há que se pensar em tecnologias que permitam a reposição de nutrientes através da reposição via biomassa, repousos, ciclagens de nutrientes (DIAS FILHO, 2007). Neste campo, acreditamos que a agroecologia tem muito a contribuir por se basear justamente em manejo dos agroecossistemas de acordo com princípios ecológicos pertinentes a cada ecossistema (GLIESSMAN, 2001).

A agroecologia busca conceber tecnologias ancoradas nos sinergismos e nas interações da biodiversidade presente nos agroecossistemas (ALTIERI, 1998) como forma de promover a sustentabilidade na agricultura. Por outro lado, ela não se restringe aos aspectos técnicos de produção, e como nos indicam Caporal e Costabeber (2004) a produção agroecológica não é um modelo ecológico de produção, mas uma forma de pensar a vida e, consequentemente, a agricultura com outros parâmetros que não os atuais econômicos e produtivos. Altieri (2012) destaca que o manejo e a preservação dos recursos naturais devem estar em consonância com a cultura local, sendo socialmente justa e economicamente viável. Enfim, a agroecologia traz consigo um caminho para autonomia de cada um na produção de seu alimento de forma saudável, o que envolve aspectos ecológicos e também sociais. Esta concepção estaria 
mais próxima da realidade e diversidade de situações que envolvem a agricultura familiar camponesa na Amazônia paraense.

Em termos mais pragmáticos, temos atualmente dois grupos principais de modelos para a intensificação agroecológica da pecuária leiteira de base familiar: i. aqueles fundamentados no pastejo rotacionado (circulação controlada dos animais em cada piquete da pastagem), tendo destaque para o Pastoreio Racional Voisin (PRV) i; e ii. outros que preconizam a incorporação de outros vegetais nas pastagens, com múltiplas funções, desde melhorar as propriedades fisicoquímicas dos solos, até servir de alimentos e/ou sombreamento para o rebanho. Outro modelo produtivo interessante, mas que ainda não teve o mesmo alcance que o rotacionado de Voisin, é aquele relacionado às áreas compostas com forragens e árvores, chamados sistemas silvopastoris, com modelos propostos, inclusive na Amazônia paraense em áreas de agricultura familiar (QUEIROZ et al., 2015). Em combinação com o rotacionado, se mostra como uma alternativa viável do ponto de vista financeiro, além de proporcionar maior bem-estar aos animais, uma vez que promove sombra.

Na Amazônia é preconizado que nas condições naturais, em pastagens implantadas sem aporte de fertilizantes, o ideal como pressão de pastejo é de 1 UA/ha/ano (VEIGA, 2006). A realidade mostra sempre um uso em desequilíbrio com esta referência, onde teremos inicialmente uma área grande para poucos animais e com o passar do tempo, a dinâmica vegetativa na área muda, tendo mais plantas adventícias que forrageira, e com o mesmo rebanho saímos de uma zona de subpastejo para outra de superpastejo, e neste ciclo a forragem vai se degradando. É nesse cenário de melhor divisão das parcelas, assim como de uma gestão do uso dos pastos focada no equilíbrio entre a carga animal e a produção forrageira, que este artigo trabalha as possibilidades de intensificação, tendo como fator principal de análise, as condições biofísicas disponíveis para as famílias.

\subsection{Paragominas: Município Verde e Microzoneamento das aptidões biofísicas}

O município de Paragominas está localizado na mesorregião Nordeste do Estado Pará, possui uma população de 114.503 habitantes e território municipal de 
$19.342,565 \mathrm{~km}^{2}$ (IBGE, 2020). O clima é de tipo Am, com médias anuais de temperatura de $26,6{ }^{\circ} \mathrm{C}$ e de pluviosidade de $1805 \mathrm{~mm}$. Do ponto de vista geológico, o município é coberto por rochas sedimentares, da série Itapecurú. A parte superior da série é formada por uma camada de argila de 30 metros, denominada argila de Belterra (KING, 1962; KOTSCHOUBEY, TRUCKENBRODT, \& CALAF, 2005b). Na sua base se formou uma espessa crosta laterítica, explorada para fabricação de alumínio (extração de bauxita). Por baixo dessas duas camadas, a serigrafia é formada por rochas mais arenosas e pouco resistentes. A erosão hídrica recortou as camadas superiores, abrindo largos vales onde afloram as camadas arenosas (KOTSCHOUBEY, TRUCKENBRODT, \& HIERONYMOUS, 1996). Por via de consequência, a geomorfologia é composta por chapadas longitudinais, formando o platô de Paragominas, e largos vales arenosos, drenados por dois rios regionais: o Capim no Oeste, e o Gurupi no Leste.

Dados do INPE (2019) indicam que a cobertura de florestas tropicais presente na área do município foi desmatada em 45\%. Desta superfície desmatada, 18\% se encontram como florestas secundárias, perfazendo assim um total de $73 \%$ de cobertura florestal em 2019. As áreas abertas são principalmente cobertas de pastagens, porém, desde o ano de 2000, a agricultura mecanizada se expandiu rapidamente nas chapadas, chegando a ocupar cerca de 150 mil ha.

A ocupação humana se deu a partir do eixo da rodovia BR-010, que corta o município de Norte a Sul na sua parte Central. Já em 1960 o governo federal atribuiu glebas de 3200 hectares aos pioneiros oriundos do sudeste do país. Estes desenvolveram a pecuária extensiva e a extração madeireira. Em 1993 foi homologada a Terra Indígena do Alto Rio Guamá de 279.000 hectares, dos quais 97.000 estão localizados no município de Paragominas, ocupando sua extremidade oriental, ao longo do rio Gurupi. A partir de 1997 foram criados assentamentos, em fazendas desapropriadas ou ocupadas. Segundo dados do INCRA (2020), as áreas ocupadas pelos assentamentos totalizam 112.500 hectares, sendo que $81 \%$ dessa superfície concentrada no setor leste do município, próximo à reserva indígena, região muito deficiente do ponto de vista do transporte rodoviário. Esse isolamento dificultou as 
condições de produção, comercialização, verticalização agropecuária. A pecuária bovina, menos sensível aos efeitos do isolamento, tornou-se uma opção frequente entre as famílias assentadas, também observado em outros locais por (FERREIRA, 2003; POCCARD-CHAPUIS, 2005;).

Diante dos inúmeros desafios em busca de um equilíbrio entre a produção e a conservação ambiental, a governança municipal em Paragominas foi inovadora ao lançar, em 2008, o projeto Município Verde, para atender às exigências do Governo Federal no quadro do Plano de Prevenção e Combate ao Desmatamento. Através desse projeto, o município desenvolveu o Cadastro Ambiental Rural (CAR), e atingiu as metas de redução do desmatamento ilegal já em 2011. A partir de 2017, começou a se consolidar uma nova proposta de governança municipal, ampliando as ações para as dimensões social e econômica. Um trabalho cartográfico permitiu identificar e mapear, em todo o município, as áreas de aptidões específicas para a intensificação das atividades agropecuárias, como também as aptidões para a produção dos chamados serviços ecossistêmicos pelas florestas.

Nesse contexto mais atual, o Plano Inteligente de Desenvolvimento Territorial (PIDT) de Paragominas, decretado em maio 2019, prevê que o mapa das aptidões se torne a base de um microzoneamento municipal, o qual buscará incentivar os produtores rurais a desenvolverem usos da terra em função das unidades pedomorfológicas (UPM) mapeadas em suas propriedades. A metodologia de cartografia das unidades, e seus potenciais para funções ecológicas e econômicas, conforme Pinillos et al. (2020), combina fatores simples e definidos de forma participativa, referentes a textura dos solos, drenagem hidrográfica e topografia, conforme descrito no quadro 2 da metodologia. 


\section{METODOLOGIA}

\section{1 Área de estudo e caracterização da pecuária leiteira}

O estudo foi desenvolvido na Comunidade de Nova Jerusalém, situada no Projeto de Assentamento Luiz Inácio, no município de Paragominas, Pará (figura 1). O Luiz Inácio, oficializado em 2006, é o maior Assentamento de Paragominas, com 34.210,7121 ha, e capacidade de assentar 625 famílias (INCRA, 2017), correspondendo a uma área média por família de 55 ha, o equivalente ao módulo fiscal do município. A instituição confirma 589 famílias com registro de beneficiário neste assentamento. Nova Jerusalém é uma das 10 comunidades que compõem o assentamento, composta por cerca de 60 famílias. Sua particularidade é a produção leiteira, atividade desenvolvida por $80 \%$ das famílias da comunidade, voltada para fabricação do queijo artesanal sob a inscrição estadual número 25 (SIE 25). Além do queijo, há criação de aves e suínos, extração de açaí, produção de farinha, pimenta do reino, caju, milho, além de canteiros com temperos e algumas ervas medicinais.

Figura 1 - Mapas de localização do Município de Paragominas no Estado do Pará e da Comunidade de Nova Jerusalém 


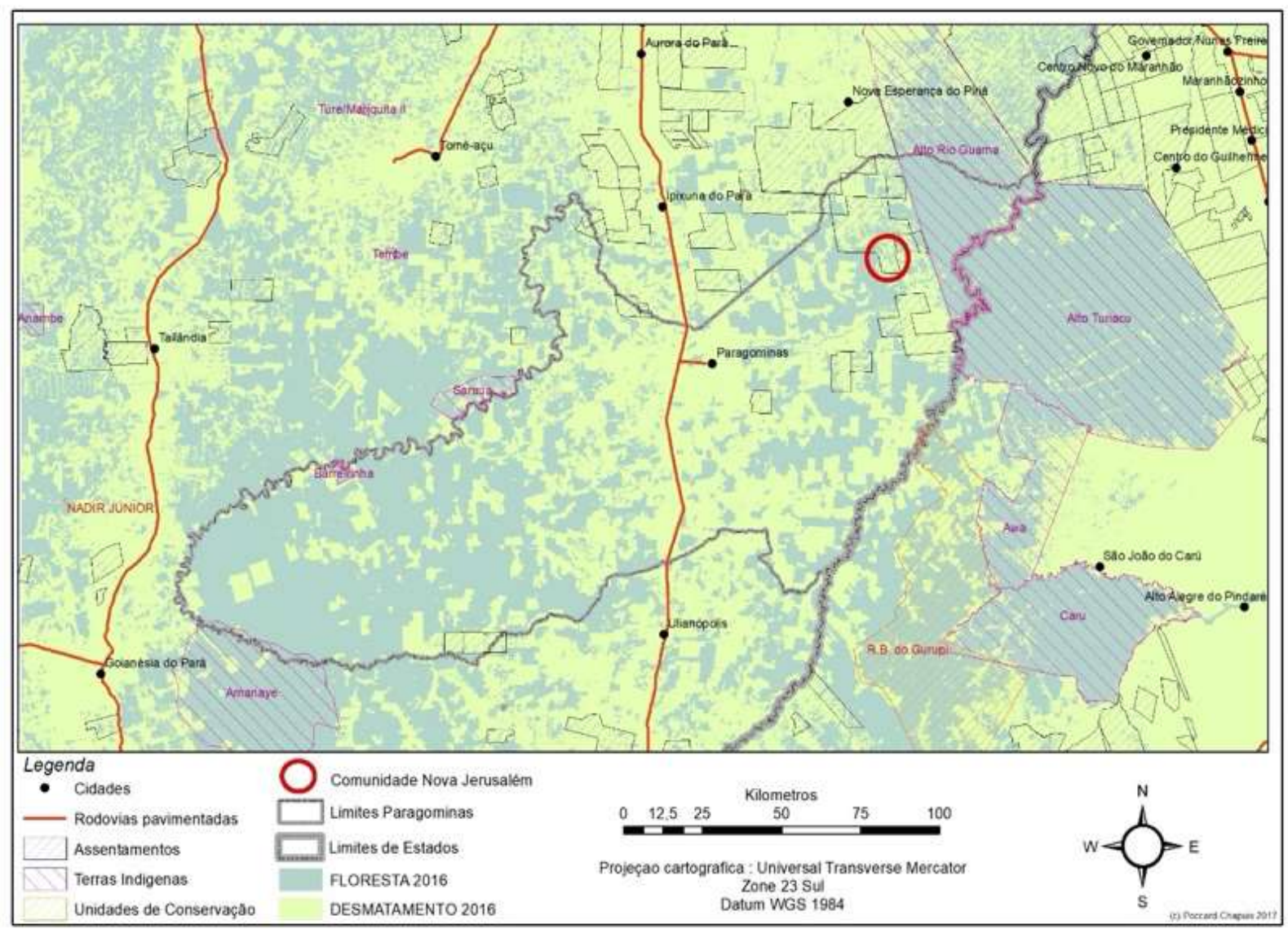

Fonte: Poccard-Chapuis (2017)

Os dados de caracterização dos sistemas produtivos das famílias foram obtidos através de trabalho de campo ao longo dos anos de 2015 a 2019, a partir de um projeto financiado pelo Banco da Amazôniaii. Houve três formas de coleta de dados:

diagnóstico da produção leiteira realizado no início das atividades (2015): no período de 12 a 15 de novembro de 2015 foram aplicados questionários para caracterização das famílias que estavam envolvidas na entrega de leite para queijaria, priorizando as 20 famílias de cooperados. Houve levantamento de informações sobre as famílias, as atividades produtivas, as fontes de renda e a pecuária leiteira. No total foram entrevistadas 26 famílias, as quais foram classificadas em três situações: cooperados que estavam entregando leite, cooperados que não estavam entregando leite, e associadosiii que estavam entregando leite.

acompanhamento das famílias a partir da instalação de experimentos em meio real: tratou-se de divisão das áreas de pastos e controle do pastejo-descanso, além da introdução de espécies leguminosas como fonte de alimento e cerca viva. Foram feitos acompanhamentos mensais das famílias (2016-2019). Inicialmente havia financiamento 
para duas unidades demonstrativas, e as duas famílias foram indicadas pela comunidade. Em seguida, houve expansão para mais quatro famíliasiv. Essas também indicadas pela comunidade e o único critério na escolha das famílias era a de ser cooperado, estando em dias com o pagamento da cota partev;

acompanhamento das famílias a partir do controle leiteiro e gestão da economia na produção do leite: as seis famílias foram acompanhadas com visitas mensais para coleta de dados de mensuração da produção leiteira e anotações sobre economia (fluxo de caixa mensal).

\subsection{Aptidões pedomorfológicas e análises espaciais}

As análises espaciais foram realizadas em Sistema de Informação Geográfica. Utilizamos o software Arcgis (c) para compilar e cruzar informações espaciais em formato shape. Com base nas superfícies dos polígonos gerados pelos cruzamentos entre arquivos, gerimos estatísticas descritivas simples referentes à extensão de áreas de aptidão em cada propriedade. O quadro abaixo (quadro 1) indica quais informações foram utilizadas, e qual é a referida fonte que disponibilizou os arquivos.

Quadro 1: Fonte de dados georreferenciados utilizados nas análises

\begin{tabular}{|l|l|}
\hline \multicolumn{1}{|c|}{ Descrição } & \multicolumn{1}{c|}{ Fonte } \\
\hline Unidades pedomorfológicas & Equipe Terracert \\
\hline Cadastro Ambiental Rural & Secretaria Estadual de Meio Ambiente do Pará \\
\hline $\begin{array}{l}\text { Perímetros de assentamentos da reforma } \\
\text { agrária }\end{array}$ & INCRA \\
\hline Limites municipais & IBGE \\
\hline Limite de Reserva Indígena & FUNAI \\
\hline Pistas rurais & SIPAM \\
\hline Rios e Igarapés & IBGE \\
\hline Cobertura Florestal & INPE; MAPBIOMAS \\
\hline Topografia - Altitude & NASA \\
\hline
\end{tabular}

Fonte: Organização dos autores

As análises espaciais envolveram 59 áreas das 60 existentes na comunidade de Nova Jerusalém. 


\subsection{Tipologia de propriedades}

Para a definição e delimitação das unidades pedomorfológicas (UPM), utilizamos a mesma do microzoneamento municipal, como descritas em Pinillos et al. (2020), e sintetizada no quadro abaixo (quadro 2). As análises partiram desta grade classificatória das condições biofísicas existentes no município de Paragominas, e dos seus recortes espaciais.

Ainda, como cada lote apresenta uma proporção de UPM própria, gerando uma grande diversidade de situações específicas, tornou-se necessário a elaboração de uma tipologia de propriedades, com a identificação de três tipos, voltada para condições biofísicas de intensificação. Os critérios definindo os tipos são as proporções de cada UPM na propriedade e a chave de classificação é definida conforme a geografia da comunidade, combinando platôs, vertentes e planície de inundação.

Quadro 2: Descrição de unidades pedomorfológicas (UPM) em Paragominas e de suas aptidões para uso da terra de acordo com microzoneamento.

\begin{tabular}{|c|c|c|c|}
\hline $\begin{array}{c}\text { Unidades } \\
\text { pedomorfológicas }\end{array}$ & $\begin{array}{l}\text { Características } \\
\text { gerais }\end{array}$ & $\begin{array}{l}\text { Uso } \\
\text { prioritário }\end{array}$ & $\begin{array}{l}\text { Aptidões das áreas, quando } \\
\text { abertas, destacando pecuária. }\end{array}$ \\
\hline Chapada & $\begin{array}{l}\text { Áreas planas, nos } \\
\text { platôs; } \\
\text { Solos permeáveis: } \\
\text { ausência de água de } \\
\text { superfície; } \\
\text { Solo argiloso e de } \\
\text { boa fertilidade; } \\
\text { Fácil mecanização. }\end{array}$ & $\begin{array}{l}\text { Atividades } \\
\text { agropecuárias }\end{array}$ & $\begin{array}{l}\text { Áreas com maior aptidão para } \\
\text { produção mecanizada. O } \\
\text { complexo da soja se concentra } \\
\text { nessa área. Para pecuária, há } \\
\text { um grande potencial para } \\
\text { sistemas integrados. Ausência } \\
\text { de água de superfície; } \\
\text { necessita de poços artesianos } \\
\text { profundos e sistemas de } \\
\text { distribuição de água } \\
\text { (canalizações ou carro pipa). }\end{array}$ \\
\hline Baixão & $\begin{array}{l}\text { Áreas onduladas a } \\
\text { levemente onduladas, } \\
\text { cobrindo as vertentes dos } \\
\text { vales; } \\
\text { Solos arenosos, } \\
\text { baixa fertilidade; } \\
\text { Recortado por } \\
\text { numerosas linhas de fluxos } \\
\text { da drenagem hidrográfica } \\
\text { (grotas); } \\
\text { Mecanização } \\
\text { possível, porém limitada. }\end{array}$ & $\begin{array}{l}\text { Atividades } \\
\text { agropecuárias }\end{array}$ & $\begin{array}{l}\text { Boas aptidões para produção } \\
\text { mecanizada, apesar de menor } \\
\text { que na chapada, devido } \\
\text { topografia, áreas recortadas } \\
\text { por grotas, e textura mais } \\
\text { arenosa. Para pecuária, são } \\
\text { áreas muito favoráveis para } \\
\text { todosos sistemas de produção } \\
\text { forrageira, inclusive os mais } \\
\text { intensivos e manejos } \\
\text { rotacionados. }\end{array}$ \\
\hline Encharcada & $\begin{array}{l}\text { Áreas planas, nas } \\
\text { partes centrais dos vales. }\end{array}$ & Floresta & $\begin{array}{l}\text { Áreas não mecanizáveis, e nem } \\
\text { podem ser adubadas } \\
\text { fortemente }\end{array}$ \\
\hline
\end{tabular}




\begin{tabular}{|c|c|c|c|}
\hline & $\begin{array}{l}\text { Solos } r \text { muito } \\
\text { arenosos, sujeitos a } \\
\text { intensa lixiviamento e } \\
\text { drenagem deficiente. } \\
\text { Próximo ao teto } \\
\text { dos lençóis freáticos } \\
\text { durante estação chuvosa, } \\
\text { impedindo mecanização } \\
\text { nessa época. }\end{array}$ & & $\begin{array}{l}\text { lixiviamento. Servem } \\
\text { tradicionalmente de reservas } \\
\text { de pastagem para estação } \\
\text { seca, e não são utilizadas na } \\
\text { estação chuvosa. Pode ser } \\
\text { melhorada pela irrigação, } \\
\text { devido à proximidade do } \\
\text { lençol freático. Uso } \\
\text { recomendado é a floresta, que } \\
\text { pode criar habitats favoráveis } \\
\text { à biodiversidade e evaporar } \\
\text { umidade na atmosfera, devido } \\
\text { umidade permanente da área. }\end{array}$ \\
\hline Encosta & $\begin{array}{l}\text { Borda de platôs, } \\
\text { forte declividade; não } \\
\text { mecanizável; } \\
\quad \text { Solo argiloso } \\
\text { (argila variegada), de baixa } \\
\text { fertilidade; } \\
\text { Processos erosivos } \\
\text { muito ativos. }\end{array}$ & Floresta & $\begin{array}{l}\text { Áreas não mecanizáveis, não } \\
\text { cultiváveis, porém } \\
\text { frequentemente desmatadas } \\
\text { em tempos anteriores. É } \\
\text { importante reflorestar essas } \\
\text { áreas para combater o intenso } \\
\text { processo de erosão, o qual } \\
\text { causa assoreamento nos vales. }\end{array}$ \\
\hline Grota & $\begin{array}{l}\text { Áreas acidentadas, } \\
\text { com fortes processos } \\
\text { erosivos. } \\
\text { mecanizável. Presença de } \\
\text { água na estação chuvosa. }\end{array}$ & Floresta & $\begin{array}{l}\text { Assim como as encostas, são } \\
\text { áreas não mecanizáveis, } \\
\text { porém frequentemente } \\
\text { desmatadas. É fundamental } \\
\text { reflorestar, para evitar erosão } \\
\text { e assoreamento. Assim as } \\
\text { grotas formam corredores } \\
\text { ecológicos, conectando matas } \\
\text { do vale com das encostas e } \\
\text { das chapadas, formando uma } \\
\text { malha florestal bem } \\
\text { conectada. }\end{array}$ \\
\hline
\end{tabular}

Fonte: Pinillos et al., (2020)

\section{RESULTADOS}

\subsection{Caracterização da produção agropecuária e uso do sol}

\subsubsection{Os sistemas são diversificados}

Os agricultores e pecuaristas familiares da comunidade de Nova Jerusalém desenvolvem diferentes atividades produtivas ligadas ao seu autoconsumo, e também para a comercialização e trocas, correspondendo bem ao perfil de agricultura familiar 
(WANDERLEY, 2014). Há destaque, dentre as atividades, para a pecuária bovina leiteira, tanto para a composição da renda quanto ao uso do espaço, sendo que $90 \%$ das famílias de Nova Jerusalém possuem bovinos. Ainda na produção animal, voltados para autoconsumo e venda esporádica na vila, possuem pequenas criações como aves, suínos, peixes e ovinos.

Nos cultivos perenes, há uma expansão da plantação de caju, com a finalidade principal de comercializar a castanha. Tem ocorrido também o plantio da pimenta do reino. Ambas estão voltadas para comercialização. Menos frequente, mas também presente, há a extração do açaí nativo, para consumo e/ou venda. Em relação aos cultivos anuais de autoconsumo, as áreas são reduzidas, em média 0,5 ha, havendo plantações de milho, arroz, hortaliças, melancia, além de mandioca para a produção de farinha. As áreas das propriedades em geral são consideradas pequenas para a realidade da região, uma vez que o módulo fiscal do município é de 55 ha, mas a média em Nova Jerusalém é de 44 ha para cada família, com $70 \%$ das famílias possuindo áreas abaixo do módulo fiscal. Mas há certa mobilidade, por exemplo, em 2019, com vendas de terras na comunidade e a reorganização espacial, observamos duas propriedades acima de 100 ha.

Em termos de uso do solo, no ano de 2015, de um total de 2.568 ha, 44\% (1155 ha) ainda eram áreas de floresta; outros $42 \%$ (1083) estavam com pastagens; $13 \%$ (328 ha) cobertos por floresta em regeneração; apenas $0,1 \%$ (2,52 ha) possuíam agricultura com algum dos cultivos acima mencionados. Trata-se claramente de um perfil voltado para a pecuária bovina, uma vez que a outra maior parte é de área com florestas, em que a utilização não é contabilizada como produtiva.

\subsubsection{A produção leiteira e a produção forrageira}

Os produtores de leite estão organizados em uma cooperativa - Cooperativa Mista Agropecuária de Nova Jerusalém (COMANJE), a qual foi fundada em 2013 na comunidade e oficializada pelos órgãos municipais (JUCEPA e ADEPARÁ) em 2014. Formalmente a cooperativa possui 20 famílias em sua fundação, mas de fato apenas 10 famílias conseguiram pagar a cota parte. A mesma fabrica e comercializa um queijo 
artesanal de tipo muçarela, principalmente na cidade de Paragominas. Possui também uma estrutura de processamento do leite, chamada de queijeira pelos moradores da comunidade, com capacidade de processamento de 1000 litros leite/dia. No entanto, até dezembro 2019, esta quantidade nunca havia sido atingida. A média gira em torno de 400 litros/dia, com baixas no verão amazônico que pode chegar a 250-300 litros dia, e máxima no inverno amazônico, com 900 litros/dia.

O número de fornecedores varia também conforme a oferta de pastagem e, consequentemente, a quantidade de leite produzida diariamente. Recebe leite de cooperados e não cooperados. Há produtores que param de fornecer leite no período mais seco. De maneira geral, as produções obtidas são baixas, mesmo se em alguns rebanhos se encontram animais de bom desempenho, as lactações oscilam entre 600 a 1200 litros/vaca/ano.

Os animais são criados unicamente a pasto, sem alimentação complementar, tendo apenas o suplemento do sal mineral, em diferentes composições, fornecido de forma irregular. As áreas cercadas onde os animais pastam, chamadas de piquetes ou mangas, são parcelas grandes variando entre 5 e às vezes mais de 20 ha, com uma carga animal oscilando entre 0,8 e 1,2 UA/ha/ano.

Os períodos de ocupação e de descanso das parcelas de pastos não são respeitados na gestão, o que leva os animais a se alimentarem ora de material muito fibroso, quando o capim cresceu demais, ora muito rico, quando o capim apenas brotou. Esta forma de gerir leva ao desgaste da forragem e o domínio da área com plantas adventícias, afetando como um todo a produção, desencadeando um processo de degradação forrageiro, e muitas vezes da área, gerando um comprometimento das características originais do solo.

Nosso experimento em campo, com divisão das áreas em parcelas menores e gestão do pasto, respeitando período de ocupação e de descanso para as gramíneas presentes, possibilitou um incremento na carga animal de 4 UA/ha/ano e um incremento de $57 \%$ na produção diária de leite no período do inverno e de $36 \%$ no período seco/verão, obtidos por nove vacas em lactação. Percebemos, no entanto, uma 
tendência de enfraquecimento da gramínea com esta carga, no curto prazo. O que a experiência nos permite afirmar é que no caso de Nova Jerusalém é possível realizar uma intensificação agroecológica da produção leiteira apenas com a divisão das áreas de pastos e gestão de seu uso de forma rotacionada. Com áreas bem formadas, ou seja, cobertura forrageira homogênea e período de descanso e de ocupação respeitado para a gramínea utilizada é possível chegar a uma carga animal de $3 \mathrm{UA} / \mathrm{ha} / \mathrm{ano}$, com a devida adubação. Isto significa triplicar a carga animal atual.

Se as alternativas existem, são as condições biofísicas presentes nas propriedades que irão definir as possibilidades para todas as famílias da comunidade participarem e se ajustarem ao uso de suas terras conforme o Plano Inteligente de Desenvolvimento Territorial de Paragominas.

\subsection{Geografia da Nova Jerusalém e as unidades pedomorfológiocas da comunidade}

\subsubsection{Contexto biofísico: o vale do Onça, entre a planície do Gurupi e o platô de Paragominas}

A comunidade Nova Jerusalém é situada na extremidade oriental do platô de Paragominas, interflúvio entre as microbacias do rio Uraim no Sul e Coaraci no Norte, o qual atinge ali suas maiores altitudes (210 metros). A comunidade é cercada ao Oeste e ao Norte pelas últimas chapadas formando o platô de Paragominas, e ao Leste por alguns morros, testemunhando a antiga extensão da chapada. No pé desses relevos estão as nascentes do Rio Onça, o qual atravessa a comunidade de Norte a Sul, desembocando no rio Uraim, principal afluente do rio Gurupi na região, 20 quilômetros ao Leste da comunidade (Figura 2).

O nível topográfico de base é determinado pela planície arenosa do Gurupi, com altitude de 10 a 15 metros acima do nível do mar. Esse desnível máximo de 200 metros entre o topo das chapadas e o rio Gurupi causa intensas erosões hídricas no período chuvoso. Tal processo recortou intensamente as chapadas, gerando encostas altas e com forte declividade, como também numerosas grotas. 
Figura 2: Topografia e hidrografia Assentamento Luiz Inácio e Comunidade Nova Jerusalém

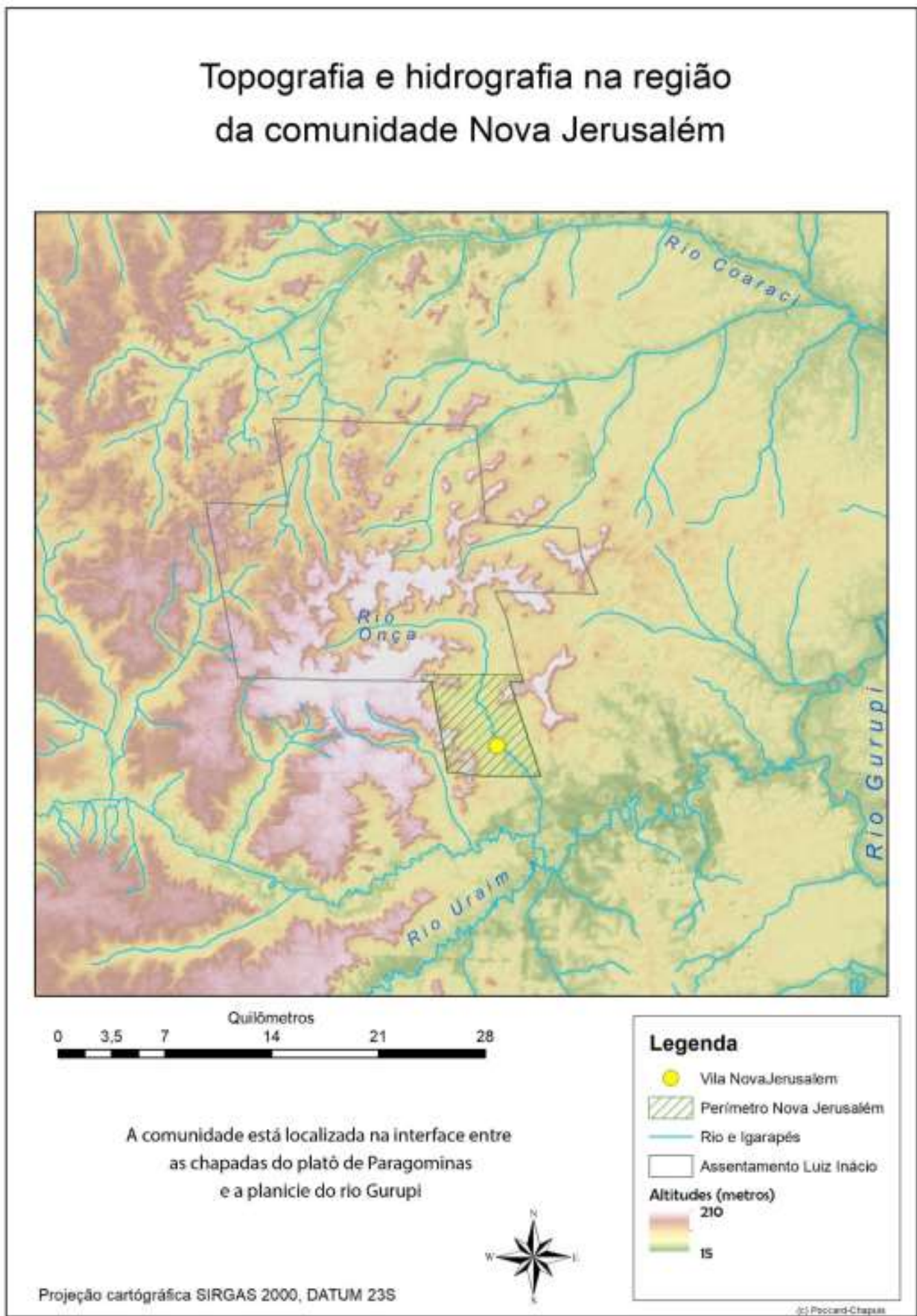

Fonte: Poccard-Chapuis, (2020), adaptado do PIDT Paragominas (2019)

A drenagem hidrográfica também é condicionada por essa geologia. Ao pé das encostas, ocorre a ressurgência das águas pluviométricas que infiltraram nas chapadas, 
cujos solos são argilosos, porém permeáveis. Dessa forma, as chapadas são secas, e nos vales se concentra uma densa rede hidrográfica, causando linhas de erosão em grotas, e também ocasionando fortes variações do lençol freático na parte central dos vales. Entre a estação chuvosa, que costumam acumular 2000 milímetros de pluviometria entre dezembro e junho, e a estação seca que costuma apresentar 10 vezes menos nos outros seis meses, estima-se que o lençol freático varie de 5 a 8 metros (GAVINA PEREIRA et al., 2018). Tais condições de drenagem dificultam a produção agropecuária e o transporte rodoviário, já que o terreno argiloso produz atoleiros épicos, e frequentes rompimentos de pontes.

O mapeamento das unidades pedomorfológicas do projeto de microzoneamento municipal retratam essa situação de contrastes entre chapadas e planícies. Grande parte do território da comunidade é ocupada pela planície do rio Onça, sendo que na parte central há uma larga área sujeita a encharcamento (figura 3). Nas laterais da zona encharcada se estendem compridas vertentes, chamadas de Baixão pelos moradores, até o pé das encostas. Os baixões são recortados por inúmeras grotas, que drenam a água ressurgente nos pés das chapadas. As encostas são numerosas e extensas devido ao nível de recorte das chapadas. Essas, por sua vez, são bem estreitas devido ao trabalho da erosão. 
Figura 3: Distribuição das unidades pedomorfológicas (UPM) na Comunidade de Nova Jerusalém

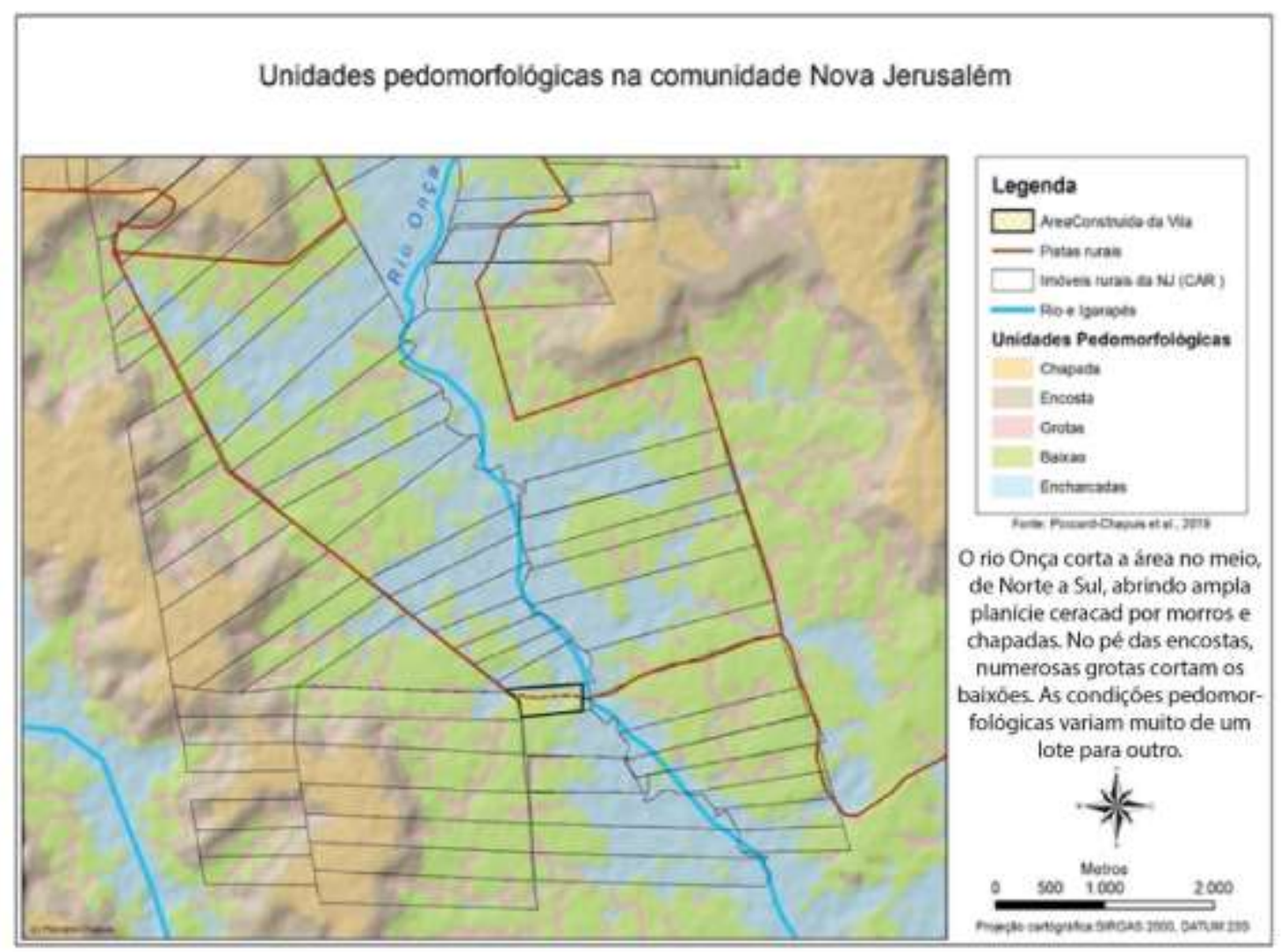

Fonte: Poccard-Chapuis,(2020), adaptado do PIDT Paragominas (2019)

A extensão da comunidade é de 2.592 ha, com predominância de áreas de Baixão com 42\%, seguida de 27\% de Encharcada, Encosta 12\%, Chapada $8 \%$ e Grotas $11 \%$. Conforme o microzoneamento, somente as áreas de Baixão e de Chapada são aptas ao uso agropecuário, enquanto as demais áreas (Encharcadas, Encostas e Grotas) devem ter seu uso preferencial de floresta. Entretanto, ao analisarmos os dados coletivamente, para área total da comunidade, esta indicação de uso não corresponde às situações encontradas em campo (tabela 1). A situação revela que não houve uma avaliação da área quanto às suas aptidões agrícolas antes de se criar o assentamento. Nessas circunstâncias, cada família utiliza as áreas que têm, independente da unidade pedomorfológica. 
Tabela 1: Valores em ha da repartição do uso da terra entre as unidades pedomorfológicas (UPMs) da Comunidade Nova Jerusalém

\begin{tabular}{lccc}
\cline { 2 - 4 } & \multicolumn{3}{c}{ Áreas em Ha } \\
\cline { 2 - 4 } & $\begin{array}{l}\text { Chapada } \\
\text { e Baixão }\end{array}$ & $\begin{array}{l}\text { Encharcada, Grota } \\
\text { e Encosta }\end{array}$ & TOTAL \\
\hline Uso Agropecuário & 643 & 442 & 1085 \\
\hline Uso Florestal & 638 & 845 & 1483 \\
\hline
\end{tabular}

*23,77 ha estavam sob classificação de nuvens e não entraram na repartição uso do solo Fonte: elaborado pelos autores a partir CAR - 2015.

As duas categorias de uso do solo aqui consideradas ocorrem indistintamente nas diferentes UPMs: pastos e florestas, estas últimas nativas ou secundárias, ocorrem em cada uma delas. Situação semelhante foi descrita por Castro et Singer (2012, pg. 35) relacionado ao uso do solo com diferentes aptidões agrícolas no assentamento Machadinho em Rondônia. As áreas consideradas boas em termos de aptidão não foram privilegiadas em detrimento das outras.

Esta repartição do uso da terra em Nova Jerusalém de 1085 ha em uso agropecuário, 1483 ha em uso florestal, indica uma proporção significativa de área florestada se comparado a assentamentos vizinhos, mas a distribuição deste uso do solo nas UPMs não permite maiores eficiências, nem para produção econômica, nem para proteção de recursos naturais. Áreas de florestas estão localizadas em UPM de aptidão para produção agropecuária, (638 ha), e áreas abertas estão localizadas em UPM de aptidão para florestas (442 ha). Implica em dizer que há subutilização do potencial agrícola das terras em $25 \%$ da área total, e em $50 \%$ da área apta para este uso. Estes resultados são inferiores ao encontrado por Amorim et al. (2017, pg. 235), em que detectaram $70 \%$ do uso abaixo do potencial da aptidão estabelecida para a área.

\subsubsection{Aptidões de cada Unidade Pedomorfológicas para intensificar a produção forrageira da comunidade}


A partir de nossa atuação em campo, verificamos algumas especificidades na produção forrageira da comunidade, que nos levam a identificar limites e propor ajustes nas aptidões de cada Unidade Pedomorfológica (UPM), em relação ao estipulado no microzoneamento do Plano Inteligente de Desenvolvimento Territorial (PIDT) de Paragominas, tal qual o mesmo foi concebido.

\subsubsection{Chapadas}

Nesta comunidade, as Chapadas se encontram no alto e ao fundo da propriedade, distante das casas e da estrada que dá acesso às propriedades. Além disso, não há disponibilidade e nem acesso direto à água. Estas condições são restritivas em três aspectos principais para a produção leiteira: i. estando distante e no alto, significa deslocamento do rebanho subindo e descendo encostas, o que, além do gasto energético que implicará na diminuição na produção diária do leite, acarreta ainda uma rota de erosão provocada pelo caminho realizado pelo rebanho; ii. não há como fornecer água aos animais sem pensar em um custo muito elevado de bombear a água para a chapada, por no mínimo 50 metros de desnível; iii. a forrageira terá um bom desenvolvimento no período chuvoso, mas na seca o problema persistirá, pois não haverá água no solo para manter a gramínea em bom estado, já que essa argila resseca muito nesse período.

Nestas condições, as áreas de chapada em Nova Jerusalém não são favoráveis para a intensificação da pecuária leiteira familiar, e podem apenas servir em manejos extensivos, com oferta de forragem para momentos críticos, como é o caso atualmente. No microzoneamento elas são classificadas como aptidão favorável, mas considerando sistemas mecanizados, e com ciclos anuais de cultivos pluviais (complexo milho soja, integração lavoura pecuária), ou com irrigação de pivô, ambas tecnologias estão atualmente fora de alcance para comunidade Nova Jerusalém. Algumas famílias têm usado para área com pimenta do reino. 


\subsubsection{Encostas}

As encostas correspondem a vertentes abruptas, nas bordas das chapadas e morros, com desnível de 50 a 80 metros. Na parte somital, elas correspondem ao afloramento da crosta laterítica que sustenta o platô, ocasionando um solo com pedregulhos ou até maciços blocos de pedras, dificultando enraizamento de qualquer vegetação. A espessura varia de 2 a 10 metros. Por baixo dessa camada somital se encontram argilas variegadas, muito compactas, ocasionando topografia acidentada marcada por profundas linhas de erosão. A fertilidade química do solo é extremamente baixa, impedindo o bom desenvolvimento vegetal, menos ainda de espécie domésticas como forrageiras. Essas áreas são ocupadas por vegetações espontâneas, frequentemente agredidas pelos incêndios, especialmente devastadores devido à declividade.

No microzoneamento são classificadas como área a reflorestar com prioridade, devido essa baixa aptidão agropecuária, e duas características importantes para serviços ecossistêmicos: (i) são áreas contínuas podendo formar corredores ecológicos importantes entre florestas de cima da chapada e dos baixões; (ii) no pé das encostas ocorrem ressurgência de água pluviométrica infiltrada na chapada e armazenada no subsolo profundo, ocasionando nascente, importante para que as famílias possam acessar água para uso doméstico e para o gado. Proteger essas áreas com vegetação florestal se torna prioritário para manter esse recurso, e por isso os sistemas produtivos devem abandonar o uso do fogo, seja para limpeza de pastagem ou para formar áreas de cultivos anuais (roça).

Em termos de intensificação da pastagem, as encostas são importantes por proteger nascentes em posição relativamente alta na topografia, possibilitando distribuição por gravidade de água para bebedouros ou represas em praças de alimentação de sistemas rotacionados.

\subsubsection{Grotas}

As grotas são áreas de erosão, localizadas nas linhas de fluxo da drenagem hidrográfica temporária. Durante a estação chuvosa, as fortes chuvas causam 
escorrimentos altamente erosivos devido à textura arenosas do solo. Essas áreas são lineares e estreitas, marcadas por forte declividade, e ligando o pé das encostas à planície central do rio, cortando as vertentes.

Tanto no microzoneamento municipal, como na realidade da comunidade Nova Jerusalém, essas áreas são impróprias para produção agropecuária. Mesmo assim, elas se encontram frequentemente desmatadas, devido ação do fogo especialmente. Apesar de não serem consideradas Áreas de Preservação Permanente (APPs), devido ao caráter intermitente da presença de água, uma cobertura florestal é útil para preservar esse recurso hídrico. Espécies economicamente úteis podem ser utilizadas.

\subsubsection{Baixões}

Os Baixões constituem a unidade pedomorfológica com maior extensão na comunidade. Eles correspondem às vertentes levemente inclinadas, situados entre os pés de encosta e a parte central da planície. O solo é arenoso, profundo, relativamente bem drenado, inclusive graças às múltiplas grotas que os atravessam. Essa configuração de topografia, drenagem e textura é favorável à produção forrageira, inclusive em modos intensivos com mecanização e adubação pesada. Taxa elevadas de lotação podem ser atingidas sem restrições do meio biofísico. Os baixões constituem a UPM mais favorável para intensificação forrageira na comunidade, assim como no microzoneamento municipal.

\subsubsection{Encharcadas}

As Encharcadas ocupam a parte central da planície do Onça, cortando a comunidade em todo seu comprimento. Elas correspondem à área afetada pelo balanço anual do lençol freático desse rio, com seu solo ficando seco e duro na estiagem, e encharcado nas cheias. A umidade residual, em horizontes cada vez mais profundos, na medida em que a estiagem avança, permite que as forrageiras permaneçam com a atividade clorofiliana por mais tempo, oferecendo folha verde para o gado. Por isso, 
alguns agricultores gostam de cultivar forragem nessa área, geralmente com variedades apropriadas como Brachiaria humidícola. Ressalta-se em contrapartida, que no período de chuva surgem atoleiros perigosos para o gado.

A aptidão desta UPM para intensificação forrageira é limitada à irrigação temporária no período de estiagem, porém isso necessita equipamentos e tecnologias ainda inexistentes na comunidade. A alternativa atual é a de usar essas áreas como reserva de forragem para o verão, com baixa produtividade e em sistema extensivo.

\subsection{Tipologia de propriedade rurais}

Estas aptidões para intensificação forrageira são importantes de serem levadas em conta, uma vez que pela geografia heterogênea da comunidade (figura 2), aliada à sua malha fundiária (figura 3), as propriedades tenham proporções diferenciadas de cada unidade pedomorfológica. Portanto, é importante para ações de desenvolvimento, visando intensificação da pecuária leiteira, ou até para gestão da cooperativa COMANJE, oferecer uma leitura clara dessa diversidade de situações. A tipologia aqui apresentada tem o propósito de agrupar as propriedades similares do ponto de vista das condições biofísicas.

Com base nos três compartimentos geomorfológicos identificados na comunidade, podemos identificar três grupos de situações: i. altos, situado do lado oeste com concentração de áreas de chapadas; ii. vertentes, com concentração das áreas de grotas e de baixão; iii. fundo de vale, com concentração de áreas encharcadas.

\subsubsection{Grupo 1: Altos}

No grupo que chamamos de Altos encontram-se sete famílias, $12 \%$ da comunidade, que têm suas terras localizadas nas áreas mais elevadas, no setor oeste da comunidade, onde estão concentradas as áreas de Chapada. Abrangem uma superfície de 245 ha, composto por 32\% de Chapadas, 48\% de Encosta, 10\% de Baixão e $10 \%$ de Grotas. Considerando que as áreas de Chapada nesta comunidade apresentam limitações para serem usadas na intensificação agropecuária, como 
explicitado mais acima neste texto, para este grupo, apenas $10 \%$ da área, o equivalente a 24 ha, são aptos a serem usados para intensificação forrageira.

O tamanho das propriedades varia entre 25 e 63 ha, sendo a mediana de 26 ha. Em termos de área passível de produção e de intensificação, a média é de 3 ha de Baixão, sendo que o mínimo registrado foi de 1 ha e o máximo de 7 ha.

Este grupo possui maiores áreas com cobertura florestal do que com uso agropecuário. Na visão do microzoneamento do município e da construção de uma paisagem ecoeficiente, observamos que as Grotas e Encostas são amplamente florestadas, o que é importante, dada as suas aptidões para essa cobertura. As chapadas também, que na comunidade possuem baixa aptidão agropecuária, são amplamente florestadas. Porém, a UPM baixão, além de rara, está coberta por floresta por mais da metade da sua área, travando as poucas perspectivas de intensificação forrageira (Tabela 2).

Tabela 2: Repartição do uso do solo por UPM do Grupo Altos

\begin{tabular}{lcccc} 
& Baixão & Chapada & $\begin{array}{c}\text { Grota e } \\
\text { Encosta }\end{array}$ & TOTAL \\
\cline { 2 - 5 } & & & & \\
Uso & 11 & 18 & $\mathbf{3 1}$ & 60 \\
Agropecuário & $\mathbf{1 3}$ & $\mathbf{6 2}$ & 110 & 185 \\
Uso Florestal & &
\end{tabular}

Fonte: Elaborado pelos autores, com base em informações do PIDT de Paragominas (2019)

\subsubsection{Grupo 2: Fundo de Vale}

Situadas ao longo da parte central da comunidade, este grupo ocupa uma área de 727 ha e abrange as propriedades com predomínio de áreas com UPM Encharcada (64\%), mas também com presença de áreas de Baixão (31\%) e de Grotas (5\%). São 17 famílias neste grupo, perfazendo uma representatividade de $29 \%$ da comunidade.

Neste grupo a área média das propriedades é de 43 ha, mas a mediana é de 33 ha, significando que metade das famílias possui área total de até 33 ha. As áreas de 
Baixão neste grupo atingem média de 13 ha, mas a mediana nos indica que metade das famílias tem menos de 9 ha de áreas possíveis de intensificar, enquanto quatro famílias têm menos de 5 ha desse tipo de UPM.

Quanto ao uso do solo, verificamos as áreas de baixão são extensas e amplamente disponíveis para uso agropecuário (60\%). Uma área equivalente é disponível para produção em Encharcada, porém com aptidões menores para intensificação agropecuária. As áreas de grotas também poderiam ser reflorestadas, a maior parte estando desmatadas (Tabela 3). Como na perspectiva desta comunidade há uma ideia de que as áreas de Encharcada possam ser utilizadas com pastos, sem, no entanto, haver a intensificação, esta relação entre uso adequado e não adequado é ainda mais favorável, na medida em que as áreas de Encharcada, utilizadas com pasto na atualidade, não precisarão ser reconvertidas em áreas florestadas. As áreas de Grota, menos presentes, podem ser reflorestadas com sistemas agroflorestais, eventualmente utilizando essências economicamente úteis, frutíferas e nativas, como o açaí (Euterpe oleracea) e o buriti (Mauritia flexuosa).

Tabela 3: Uso do solo por unidade pedomorfológica do Grupo Fundo de Vale

\begin{tabular}{lcccc} 
& \multicolumn{4}{c}{ Áreas em Ha } \\
\cline { 2 - 5 } & Baixão & Encharcada & Grota & TOTAL \\
\hline Uso Agropecuário & 135 & 133 & 20 & 288 \\
Uso Florestal & $\mathbf{9 0}$ & $\mathbf{3 3 1}$ & 17 & 438 \\
\hline
\end{tabular}

Fonte: Elaborado pelos autores, com base em informações do PIDT de Paragominas (2019)

\subsubsection{Grupo 3: Vertentes}

Este Grupo concentra os lotes situados mais a leste da comunidade, sendo o grupo com maior representatividade na comunidade, 35 famílias (59\%), ocupando 1.622 ha dos 2.592 ha que perfazem a área de Nova Jerusalém. É marcado pela presença dominante de UPM Baixão (52\%), seguida de uma menor parcela de Encharcada (15\%), Grotas (13\%), Encostas (12\%) e $8 \%$ de Chapada.

Quanto ao tamanho das propriedades, há uma grande diversidade, variando entre 7 ha e 103 ha. Média e mediana são coincidentes, com 46 ha, que emb ora abaixo 
do módulo fiscal do município, comparativamente aos demais grupos, podemos considerar uma área grande. Destaca-se que quatro famílias possuem abaixo de 10 ha. Em termos de áreas para intensificação (UPM Baixão), média e mediana de 24 e 23 ha respectivamente, refletem as maiores áreas por família se comparado aos grupos anteriores, sendo que uma propriedade chega a ter 59 ha de Baixão. Em termos de possibilidades de aumentar a produtividade e a renda financeira a partir da intensificação da pecuária, conforme o microzoneamento, estas são as famílias com as melhores condições biofísicas em suas propriedades.

Ressalta-se uma extensa área com boa aptidão para intensificação forrageira coberta por florestas (362 hectares, Tabela 4). Se as chapadas são quase integralmente florestadas, há um déficit florestal de 148 hectares nas grotas e Encostas.

Tabela 4: Uso do solo por unidade pedomorfológica Grupo Vertentes

\begin{tabular}{lcccccc} 
& \multicolumn{7}{c}{ Áreas em Ha } \\
\cline { 2 - 7 } & Baixão & Chapada & Encharcada & Encosta & Grota & TOTAL \\
\hline Uso Agropecuário & 477 & 2 & 105 & 38 & 110 & 732 \\
Uso Florestal & 362 & 114 & 137 & 148 & 105 & 866 \\
\hline
\end{tabular}

Fonte: Elaborado pelos autores, com base em informações do PIDT de Paragominas (2019)

\subsection{Limites e potencialidades do microzoneamento para intensificação forrageira na Nova Jerusalém}

Devido ao recorte da malha fundiária, existe uma grande heterogeneidade entre as propriedades, em termos de possibilidades de intensificação forrageira. Algumas possuem mais áreas aptas (tipo Vertentes), outras menos (tipo Fundo do Vale), e outras muito menos (Tipo Altos). Nos sistemas atuais extensivos e de baixa produtividade, as diferenças entre propriedades provêm, sobretudo, das superfícies de pastagem em 
cada uma delas. Porém, novas desigualdades surgirão com o processo de intensificação, e dessa vez com base nas aptidões biofísicas disponíveis por propriedade.

No geral, o que observamos é que a maior limitação para as famílias em se apoiarem no microzonemanto e realizarem mudanças em direção a sistemas produtivos mais eficientes em termos ecológicos e econômicos se restringe às parcelas de UPM Baixão em suas áreas. Percebemos um gradiente entre os grupos, que coloca o grupo 1 em situação de maior vulnerabilidade, com as menores áreas e o grupo 3 com possibilidades excelentes, posto que há áreas acima de 23 ha para metade das famílias.

Quanto aos ajustes entre o uso adequado das UPMs, para todos os grupos observamos a mesma tendência, de uso aleatório, entre adequado e não adequado envolvendo todas as UPMs. Este resultado nos levam a crer, como descrito por Plassin et al (2017), que as escolhas para uso das áreas são baseadas em acesso e proximidade da casa de moradia, e não em tipo de solo e/ou relevo. Ressalta-se, no entanto, que metade da área destinada ao uso agropecuário ainda se encontra com floresta, podendo ser um fator limitante, uma vez que a legislação não permite novas aberturas.

Podemos destacar que não é o tamanho da propriedade em si que determina as possibilidades de intensificação para família, mas a localização dentro da geografia da comunidade de Nova Jerusalém.

A tabela abaixo (tabela 5) nos fornece uma comparação entre os grupos em que as fragilidades em termos de áreas para intensificação da pecuária no grupo 1, Altos, fica evidente. Não só para intensificar, pois eles não possuem área de Encharcada para serem usadas de forma mais extensiva pela pecuária. Neste estudo, estas sete famílias são as que se encontram em situação mais vulnerável frente ao microzoneamento, realçando as condições em que estas famílias trabalham hoje e quais perspectivas são possíveis de serem pensadas. Para este grupo um apoio para investimento na área de Chapada é sem dúvida a maior indicação.

Tabela 5: Síntese comparativa das áreas possíveis de uso com pastos por grupo

\begin{tabular}{l|cc|cc}
\hline Altos (Áreas ha) & \multicolumn{2}{|l|}{ Fundo de Vale (Áreas ha) } & Vertentes (Áreas ha) \\
\hline Baixão & Encharcada & Baixão & Encharcada & Baixão $\quad$ Encharcada \\
\hline
\end{tabular}




\begin{tabular}{lll|cl|cl} 
Média & 3 & 0 & 13 & 27 & 24 & 12 \\
Min. & 1 & 0 & 2 & 8 & 4 & 1 \\
Máx. & 7 & 0 & 43 & 75 & 59 & 40 \\
Mediana & $\mathbf{3}$ & 0 & $\mathbf{9}$ & 29 & $\mathbf{2 3}$ & 10 \\
\hline
\end{tabular}

Fonte: Elaborado pelos autores, com base em informações do PIDT de Paragominas (2019)

As estratégias e práticas de intensificação forrageiras podem variar de um grupo para outro. Se o primeiro passo, em todas propriedades, seria de dividir e manejar os pastos nas UPM baixões, já que o manejo rotacionado ali constitui a opção mais acessível, o segundo passo varia de um tipo para outro. As propriedades do grupo Alto vão rapidamente encontrar os limites espaciais dos baixões que possuem e, portanto, ter que efetuar um salto tecnológico para aumentar mais ainda a produção: levar água para chapada e manejar o pasto lá em cima, ou passar para o manejo intensivo nos baixões, com adubação mais pesada e irrigação.

No grupo Fundo do Vale, a situação é similar. Com pouco baixão disponível, os produtores vão ter que partir para mais tecnologias. Ali tam bém, o salto para sistemas intensivos irrigados / pesadamente adubados também seria a opção. Já no grupo de Vertentes, o manejo rotacionado pode ser estendido em grandes áreas, opção mais fácil do que os referidos saltos tecnológicos. Em todas essas perspectivas, deve se contar também com a escassez de recursos humanos qualificados.

Fazendo uma projeção de ganhos produtivos e financeiros com a elevação da carga animal utilizada hoje na comunidade (0,8 a 1,2 UA/ha/ano) a partir do estabelecimento homogêneo da cobertura forrageira, divisão e uso rotativo dos pastos e aliado à introdução de árvores leguminosas, teríamos o seguinte cenário: i. o grupo Altos poderia manter até cinco vacas em lactação em sua área de baixão, pensando em um máximo de intensificação (3 UA/ha/ano). Com os rebanhos atuais, teria uma média de 2.400 litros de leite/ano e três bezerros. Já o grupo Fundo de Vale poderia manter até 27 UA em sua área, em torno de 20 vacas e 16 bezerros, o que refletiria em 12.800 litros por ano e 16 bezerros; e para o último Grupo, Vertentes, esta possibilidade 
aumenta consideravelmente para $69 \mathrm{UA}$, equivalendo aproximadamente a 55 vacas e 41 bezerros, dando 32.800 litros/ ano e 41 bezerros. Este intervalo entre 5 e 55 vacas é bem importante, demonstrando as diferenças infligidas às famílias se considerando apenas os aspectos biofísicos de suas propriedades.

\section{CONSIDERAÇÕES FINAIS}

As aptidões das UPM em Nova Jerusalém não correspondem na sua íntegra, ao microzoneamento. As especificidades da comunidade, nos levam a reformular a descrição das aptidões de cada UPM. Grotas e Encostas são as únicas que permanecem com a mesma aptidão, florestal ou agroflorestal. As Chapadas não têm aptidão para intensificação forrageira nas condições atuais, apenas para pastejo extensivo, assim como as Encharcadas. Os Baixões são as únicas áreas com boas aptidões de intensificação forrageira, com base em práticas alcançáveis pelos agricultores. Isto significa que a Intensificação Agroecológica da pecuária pode ser uma solução eficaz para as famílias que possuem pelo menos 10 ha de UMP Baixão, o que corresponde a $56 \%$ das famílias de Nova Jerusalém.

A cobertura florestal não é repartida de maneira otimizada entre as UPM. Conforme as aptidões especificas na comunidade descritas acima, há um déficit de 199 hectares de florestas em área de Grotas e de Encostas. Por ou tro lado, 465 hectares de Baixão são cobertos por floresta, apesar da aptidão para intensificação forrageira. Em algumas propriedades, especialmente as do grupo Altos, essas florestas na UPM mais apta pode travar o desempenho econômico, à medida que o processo de intensificação ocorre. Da mesma forma, ocorrem em Grotas e Encostas desmatadas, desperdícios de recursos naturais.

A leitura de reordenamento a partir das unidades pedomorfológicas evidencia com mais clareza a situação de Nova Jerusalém, e pode servir de orientação para o planejamento de apoio às famílias mais vulneráveis, pois estas terão dificuldade para se manterem na terra. Ou seja, não basta termos soluções técnicas disponíveis e recursos financeiros, se o próprio meio biofísico é um limitante. Parte dessas famílias 
não devia estar assentadas onde estão. E para estas famílias, de maior vulnerabilidade, uma atenção especial deve ser dada pelas instituições locais a fim de apoiar mudanças e sistemas produtivos que permitam às famílias permanecerem de forma digna em campo.

As possibilidades com a intensificação agroecológica dos pastos são promissoras e bem mais produtivas que a situação atual, entretanto os investimentos para isto também são elevados. Para os agricultores interessados nestas mudanças, faz-se necessário empreender alguns aportes, que poderiam ser fomentados por políticas públicas, como a formação e capacitação dos mesmos nas alternativas técnicas disponíveis, além de acesso ao crédito.

Ressaltamos que mesmo que a intensificação da pecuária não seja a solução de todos, ela pode ser para uma maioria. Além disto, tendo em vista ser uma comunidade tradicionalmente leiteira, esta intensificação é uma possibilidade que deve seguir a ordem do dia, sendo assumida pelas instituições de pesquisa e desenvolvimento local.

\section{REFERÊNCIAS}

ALTIERI, M. Agroecologia. A dinâmica produtiva da agricultura sustentável. Porto Alegre. Ed. Universidade/UFRGS, 1998.

ALTIERI, M. Colheita fatal: velhas e novas dimensões da tragédia ecológica da agricultura moderna. In: ALTIERI, M. Agroecologia: bases científicas para uma agricultura sustentável. $3^{a}$ Ed. (Revista e Ampliada), São Paulo: Expressão Popular, 2012.

AMORIM, J. V. A. et al. Adequabilidade do uso agrícola das terras do sertão central do Ceará. Revista Brasileira de Geografia Física, Recife, v. 10, p. 228-238, 2017.

CAPORAL, F.R.; COSTABEBER, J. A. Agroecologia e Extensão Rural: contribuições para a promoção do desenvolvimento rural sustentável. Brasília: MDA/SAF/DATER-IICA, 2004.

CARVALHO, S. A.; POCCARD-CHAPUIS, R.; TOURAND, J. F. Opportunism and persistence in milk production in the Brazilian Amazonia. Revue d'Elevage et de Medecine Veterinaire des Pays Tropicaux (Online), v. 68, p. 61-67, 2015.

CASTRO, M. C; SINGER, B.H. Agricultural Settlement and Soil Quality in the Brazilian Amazon. Population and Environment, 34(1): 22 - 43, 2012. 
CIADELLA, N. et al. Do political changes aimed at reducing Amazonian deforestation contribute to ecological intensification? Agricultures (Montrouge) / Cahiers d'Études et de Recherches Francophones, v. 24, p. 246-254, 2015.

CLAUDINO, L. S. D.; FERREIRA, L. A.; POCCARD-CHAPUIS, R. A diversidade de condições socioeconômicas dos pecuaristas e a gestão das pastagens no sul do Pará. Revista Brasileira de Gestão e Desenvolvimento Regional, Taubaté, SP. v.12, n.2, p.138-160, 2016.

CLAUDINO, L. S. D. et al. Transformações nos territórios de produção bovina pelo desenvolvimento do setor agropecuário: estudo comparativo entre Brasil e Uruguai. Revista IDEAS (Online), v. 7, p. 8-42, 2013.

DIAS FILHO, M. B. Degradação de pastagens: processos, causas e estratégias de recuperação. 3. ed. Belém: Embrapa Amazônia Oriental, 2007.

FERREIRA, L. A. Evolução e perspectiva para a agricultura familiar do Município de Uruará: pistas para uma reflexão sobre a consolidação dos sistemas de produção agrícolas familiares. Coleta Amazônia, Belém, v. 1, n.1, p. 88-110, 2003.

FRANCA, B. B.; LIMA, J. J. M.; SOUSA, K. A.; LIMA, L. F. A.; SANTOS, M. A.; CARMO, S. S.; RAMOS, M. R. Capacidade de uso e aptidão agrícola de uma fazenda em São Domingos do Araguaia (PA). Revista Geonorte, v. 10, p. 134-153, 2019.

GAVINA PEREIRA J. L., et al. Avaliação de ferramentas automáticas para a extração da rede de drenagem a partir de dados de elevação SRTM para o município de Paragominas, estado do Pará, Brasil. Boletim do Museu Paraense Emílio Goeldi. Ciências Naturais, 13 (3): p. 409-433, 2018.

GLIESSMAN, S.R. Agroecologia: processos ecológicos em agricultura sustentável. Porto Alegre: Ed. Universidade/UFRGS, 2001.

INCRA, 2020. Painel de Assentamentos. Disponível em: http://painel.incra.gov.br/sistemas/index.php. Acesso em 29/04/2020

INPE, 2019. Instituto Nacional de Pesquisas Espaciais, Coordenação Geral de Observação da Terra. Programa de monitoramento da Amazônia e demais biomas. Desmatamento Amazônia Legal. Disponível em: <http://terrabrasilis.dpi.inpe.br/downloads/>. Acesso em: 30 abril. 2019.

HEREDIA, B. M. A. et al. Análise dos impactos regionais da reforma agrária no Brasil. Estudos Sociedade e Agricultura (UFRJ), Rio de Janeiro, v. 1, n.1, p. 73-111, 2002.

KING, L. C. The morphology of the earth. Edinburgh: Oliver and Boyd. 1962.

KOTSCHOUBEY, B., TRUCKENBRODT, W., \& HIERONYMOUS, B. Depósitos de caolim e argila semi-flint no nordeste do Pará [Kaolinite and clay semi-flint deposits in north- eastern Pará]. Rev. Bras. Geoc., 26, 71-80, 1996.

KOTSCHOUBEY, B., TRUCKENBRODT, W., \& CALAF, J. M. C. Evolução geologica da porção meridional da Província bauxitífera de Paragominas durante o Néogeno/ Pleistoceno (Noroeste da Bacia do Grajaú, nordeste do Pará e extreme oeste do Maranhão) [Geological evolution of 
the southern part of Paragominas bauxite province during the Neogene/Pleistocene (Northwestern of the Grajaú Basin, North-eastern of Pará and far west of Maranhão)]. Rev. Bras. Geoc., 35, 263-272, 2005.

LEPSCH, I. F.; BELLINAZZI Jr., R.; BERTOLINI, D.; Espíndola, C. R. Manual para levantamento utilitário do meio físico e classificação de terras no sistema de capacidade de uso. 4a Aproximação. 2. ed. Campinas: Sociedade Brasileira de Ciência do Solo, 1991.

MACEDO, S.; MOREAU, M. S.; SPANGHERO, P. E. S. F. Caracterização morfométrica e uso e ocupação da terra da microbacia hidrográfica do rio Água Branca de Itabuna-BA. Revista Geonorte, v. 10, p. 82-99, 2019.

NIEMANN, R. S. Levantamento do meio físico e classificação das terras no sistema de capacidade de uso da Microbacia do Ribeirão Putim. Relatório de trabalho desenvolvido na disciplina de Introdução ao Geoprocessamento do Curso de Pós-Graduação em Sensoriamento Remoto. INPE: São José dos Campos, 2012.

PEREIRA, L. C.; NETO, F. L. Avaliação do potencial agrícola das terras: proposta metodológica. Jaguariúna: Embrapa Meio Ambiente. 2004.

PEDRON, F. A. et al. A aptidão de uso da terra como base para o planejamento da utilização dos recursos naturais no município de São João do Polêsine - RS. Ciência Rural, Santa Maria, v.36, n.1, p.105-111, 2006.

PINILLOS, D. et al. Understanding Landscape Multifunctionality in a Post-forest Frontier: Supply and Demand of Ecosystem Services in Eastern Amazonia. Frontiers in Environmental Science, v. 7, p. 1-16, 2020.

PLASSIN, S. S. et al. Landscape and intensification of cattle ranching in Brazilian Amazon: New spatiotemporal dynamics at farm level. Confins (PARIS), v. 1, p. 125-151, 2017.

POCCARD-CHAPUIS, R. et al. Des cendres de la forêt à l'économie verte, l'évolution agraire en Amazonie orientale traduit-elle un mouvement d'intensification écologique? Fourrages, p125$133,2015$.

POCCARD-CHAPUIS et al. A cadeia produtiva da carne: uma ferramenta para monitorar as dinâmicas nas frentes pioneiras na Amazônia brasileira? Cadernos de Ciência \& Tecnologia, v. 22, p. $125-138,2005$.

QUEIROZ, J. F.; MANESCHY, R. Q.; MARQUES, M. N. C. Modelos econômicos de sistemas silvipastoris com cercas vivas. Cadernos de Agroecologia, v. 10, p. 17-21, 2015.

RAMALHO FILHO, A.; BEEK, J. K. Sistema de avaliação da aptidão agrícola das terras. 3 Ed. Rev. Rio de Janeiro. EMBRAPA-CNS. 1995. 68p.

RAMALHO FILHO, A; PEREIRA, L. C. Aptidão agrícola das terras do Brasil: potencial de terras e análise dos principais métodos de avaliação. Rio de Janeiro. Embrapa Solos. 1999. 46p. (Documentos 1) 
SILVA, J. M. L. et al. Avaliação da aptidão agrícola das terras do município de Acrelândia, Estado do Acre. Belém:Embrapa Amazônia Oriental, 2002. 27p. (Documentos, 146)

SILVA, E. B.; NOGUEIRA, R. E.; UBERTI, A. A. A. Avaliação da aptidão agrícola das terras como subsídio ao assentamento de famílias rurais, utilizando Sistemas de Informações Geográficas. Revista Brasileira Ciência do Solo. V.34, p.1977-1990, 2010.

VAZ, V. et al. A Pecuária na Agenda Ambiental da Amazônia Brasileira: percepções e representações dos atores locais. In: Jalcione Almeida; Cleyton Gerhard; Sônia Magalhães. (Org.). Contextos Rurais e Agenda Ambiental no Brasil: práticas, políticas, conflitos, interpretações. 1ed.Belém: Rede de estudos rurais, 2012, v. 1, p. 64-90.

VEIGA J. B. et al. Expansão e trajetórias da Pecuária na Amazônia. 1. ed. Brasíla, DF: UnB, 2004.

VEIGA, J. B. Formação e manutenção de pastagem. In: Jonas Bastos da Veiga. (Org.). Criação de gado leiteiro na Zona Bragantina. 1ed.Belém, PA: Embrapa Amazônia Oriental, 2006, v. 1, p. $59-65$

VILLELA, F. N. J.; MANFREDINI, S.; CORREA, A.J.M.; CARMO, J.B. Morfopedologia e zoneamento voltado à ocupação. Revista Departamento de Geografia. USP, v.30, p.179-192, 2015.

WANDERLEY, M. N. B. O campesinato brasileiro: uma história de resistência. Revista de Economia e Sociologia Rural (IMPRESSO), v. 52, p. 25-44, 2014.

\footnotetext{
' Inicialmente estabelecido como um manejo convencional ultra intensivo - Pastoreio Racional Voisin - o qual foi preconizado para aumento de ganho por área, assim como aproveitar melhor desempenho da planta forrageira, hoje é a base de diferentes formas de melhor gestão do recurso forrageiro e ambiental. Lenzi (2012) descreve os 4 passos fundamentais estabelecidos por André Voisin em 1974, necessários para o bom desempenho do sistema. $O$ repouso da gramínea é a fase crucial, pois permitirá a concentração de carboidratos necessário para um bom crescimento sem desgaste da raiz, assim como o tempo de pastoreio, onde a forragem não deve sofrer mais de um corte no mesmo período.

ii Projeto intitulado: Desafios da pecuária familiar leiteira: inovações para uma gestão sustentável da pecuária, sob a coordenação de Soraya Abreu de Carvalho (INEAF/UFPA), financiado pelo Banco da Amazônia. Este projeto foi uma demanda da comunidade identificada no trabalho de campo realizado nos anos de 2012/2013, por uma equipe interdisciplinar de pesquisadores de diferentes instituições dentro do projeto ECOTERA (UFPA, EMBRAPA-Amazônia Oriental e CIRAD), juntamente com os discentes do curso de Especialização em Agriculturas Amazônicas e Desenvolvimento Agroambiental - DAZ, ofertado pelo Núcleo de Ciências Agrárias e Desenvolvimento Rural da UFPA, em seu Programa de Pós Graduação em Agriculturas Amazônicas.

iii Famílias que moram na comunidade e fazem parte da associação do assentamento, mas que ainda não tinham conseguido se inserir na cooperativa devido ao pagamento da cota parte.

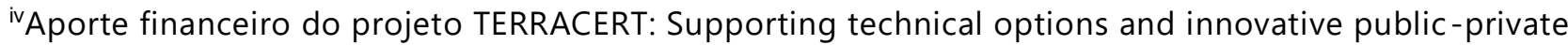
partnerships by linking sustainable beef cattle production and enhanced landscape management, CIFOR, através do programa Climate Change and Food Security, entre 2015 e 2018. Coordenado por Pablo Pacheco.

${ }^{\vee} \mathrm{Na}$ época apenas 10 famílias haviam conseguido pagar a cota parte da cooperativa (COMANJE).
} 